medRxiv preprint doi: https://doi.org/10.1101/2021.07.12.21260365; this version posted July 15, 2021. The copyright holder for this preprint (which was not certified by peer review) is the author/funder, who has granted medRxiv a license to display the preprint in perpetuity.

All rights reserved. No reuse allowed without permission.

\title{
Birth during the COVID-19 pandemic, but not maternal SARS-CoV-2 infection during pregnancy, is associated with lower neurodevelopmental scores at 6-months
}

\begin{abstract}
*Lauren C. Shuffrey $\mathbb{D}^{1}$, *Morgan R. Firestein $\mathbb{D}^{1}$, Margaret Kyle $\mathbb{D}^{2}$, Andrea Fields $\mathbb{D}^{3}$, Carmela Alcántara ${ }^{4}$, Dima Amso $^{3}$, Judy Austinn ${ }^{5}$, Jennifer M. Bain ${ }^{6}$, Jennifer Barbosa ${ }^{1}$, Mary Bence ${ }^{2}$, Catherine Bianco ${ }^{3}$, Cristina Fernández ${ }^{2}$, Sylvie Goldman ${ }^{6}$, Cynthia Gyamfi-Bannerman ${ }^{7}$, Violet Hott ${ }^{2}$, Yunzhe Hu ${ }^{1}$, Maha Hussain ${ }^{2}$, Pam Factor-Litvak ${ }^{8}$, Maristella Lucchini ${ }^{1}$, Arthur Mandel ${ }^{6}$, Rachel Marsh ${ }^{1}$, Danielle McBrian ${ }^{6}$, Mirella Mourad ${ }^{9}$, Rebecca Muhle ${ }^{1}$, Kimberly Noble ${ }^{10}$, Anna Penn ${ }^{2}$, Cynthia Rodriguez ${ }^{11}$, Ayesha Sania ${ }^{1}$, Wendy G. Silver ${ }^{6}$, Kally C. O’Reilly ${ }^{1,11}$, Melissa Stockwell ${ }^{2}$, Nim Tottenham ${ }^{3}$, Martha G. Welch ${ }^{1,2,12}$, Noelia Zork ${ }^{9}$, William P. Fifer ${ }^{1,2}{ }^{1,}$ Catherine Monk (D) ${ }^{1,9}$, Dani Dumitriu(D) 1,2
\end{abstract}

\footnotetext{
${ }^{1}$ Department of Psychiatry, Columbia University Irving Medical Center, New York, NY 10032

${ }^{2}$ Department of Pediatrics, Columbia University Irving Medical Center, New York, NY 10032

${ }^{3}$ Department of Psychology, Columbia University, New York, NY 10027

${ }^{4}$ School of Social Work, Columbia University, New York, NY 10027
}

${ }^{5}$ Heilbrunn Department of Population and Family Health, Columbia University Irving Medical Center, New York, NY 10032

${ }^{6}$ Department of Neurology, Division of Child Neurology, Columbia University Irving Medical Center, New York, NY 10032

${ }^{7}$ Department of Obstetrics, Gynecology and Reproductive Sciences, University of California San Diego, La Jolla, CA 92037

${ }^{8}$ Department of Epidemiology, Mailman School of Public Health, Columbia University Irving Medical Center, New York, NY 10032

${ }^{9}$ Department of Obstetrics and Gynecology, Columbia University Irving Medical Center New York, NY 10032

${ }^{10}$ Department of Neuroscience and Education, Teachers College, Columbia University, New York, NY 10027

${ }^{11}$ New York State Psychiatric Institute, New York, NY 10032

${ }^{12}$ Department of Pathology and Cell Biology, Columbia University Irving Medical Center, New York, NY 10032

*Drs. Shuffrey and Firestein contributed equally to this article.

The intrauterine environment strongly influences development. Neurodevelopmental effects of in utero exposure to maternal SARS-CoV-2 infection are widely speculated but currently unknown. The COVID19 Mother Baby Outcomes (COMBO) initiative was established at Columbia University Irving Medical Center (CUIMC) in New York City to prospectively study the health and wellbeing of infants with and without in utero exposure to maternal SARS-CoV-2 infection. We report findings on 6-month neurodevelopmental outcomes using the parental-report Ages \& Stages Questionnaire, $3^{\text {rd }}$ Edition (ASQ-3), from 107 in utero exposed and 131 unexposed full-term infants born between March and December, 2020. We compare these infants to a historical cohort comprised of 62 infants born at CUIMC at least two months prior to the onset of the pandemic. In utero exposure to maternal SARS-CoV-2 infection was not associated with differences on any ASQ-3 subdomain regardless of infection timing or severity, however, infants born during the pandemic had significantly lower scores on gross motor, fine motor, and personal-social subdomains when compared to the historical cohort. Infants born to women who were in the first trimester of pregnancy during the peak of the pandemic in NYC had the lowest personal-social scores. Birth during the pandemic, but not maternal SARS-CoV-2 infection, was associated with differences in neurodevelopmental outcomes at 6-months. These early findings suggest significantly higher public health impact for the generation born during the COVID-19 pandemic than previously anticipated.

Corresponding Author:

Dani Dumitriu, M.D., Ph.D.

New York State Psychiatric Institute

Columbia University Irving Medical Center

1051 Riverside Drive, Suite 4807

New York, NY 10032

dani.dumitriu@columbia.edu 
medRxiv preprint doi: https://doi.org/10.1101/2021.07.12.21260365; this version posted July 15, 2021. The copyright holder for this preprint (which was not certified by peer review) is the author/funder, who has granted medRxiv a license to display the preprint in perpetuity. All rights reserved. No reuse allowed without permission.

\section{Introduction}

Globally, over 200 million infants have been born since the onset of the COVID-19 pandemic. During the first two weeks of universal testing at the height of the pandemic in New York City (NYC), 14\% of laboring women in the Columbia University Irving Medical Center (CUIMC) hospital system tested positive for severe acute respiratory syndrome coronavirus 2 (SARS-CoV-2) by nasopharyngeal polymerase chain reaction $(\mathrm{PCR})^{1}$. To date, $2 \%$ of the world's population has been infected at some point during the pandemic. While impossible to precisely quantify, even the most conservative estimates of the total number of infants worldwide with in utero exposures to maternal SARS-CoV-2 infection range in the millions.

Fetal exposure to perturbations of the intrauterine environment is implicated in altered brain development and long-term offspring vulnerability for neurodevelopmental and psychiatric sequelae ${ }^{2-15}$. Although vertical transmission of SARS-CoV-2 from mother to fetus is exceedingly rare ${ }^{16-20}$, data from prior human coronavirus outbreaks (severe acute respiratory syndrome (SARS), Middle East respiratory syndrome (MERS)) suggest that severe infection during pregnancy may not only impact maternal health ${ }^{21}$, but may also increase risk for several adverse infant outcomes through mechanisms related to maternal immune activation ${ }^{22}$. Other viral illnesses during pregnancy are associated with higher risk for neurodevelopmental deficits, including motor delays $^{23}$, as in the case of in utero HIV-exposed uninfected infants ${ }^{5-15}$. Additional epidemiological support for this association comes from naturalistic studies of viral epidemics that identified populationlevel impacts. Cohort studies of the generation born during the $1918 \mathrm{H} 1 \mathrm{~N} 1$ pandemic found lower child educational attainment and adult socioeconomic status $^{24}$. The 1964 rubella pandemic led to a 10-15fold increase in autism spectrum disorder or schizophrenia in offspring ${ }^{25,26}$. There is a critical need to determine the neurodevelopmental effects of fetal exposure to maternal SARS-CoV-2 infection ${ }^{27-31}$, especially given the well-established benefits of early identification of at-risk children ${ }^{32-34}$.

The COVID-19 Mother Baby Outcomes (COMBO) Initiative is a prospective matched casecontrol study established at CUIMC in Spring 2020 to examine the effects of in utero exposure to maternal SARS-CoV-2 infection on the health and wellbeing of both mother and child living in the first U.S. pandemic epicenter (www.ps.columbia.edu/COMBO). Based on evidence from prior studies $23,35,36$, we hypothesized maternal SARS-CoV-2 infection during pregnancy would be associated with delays in social and motor development at 6-months of age. Additionally, we compared infants born during the COVID-19 pandemic to a historical cohort born at the same medical center using the same neurodevelopmental assessment.

\section{Participants and Methods}

\section{Study design and participants}

This analysis includes infants enrolled in the COMBO Initiative born between March and December, 2020, and an available historical comparison cohort of infants born at the same institution between November, 2017 and January, 2020. Data using the same 6-month postnatal neurodevelopmental measures were available for participants enrolled in both of these cohorts. Preterm delivery (gestational age (GA) <37 weeks) was an exclusionary criteria for the historical cohort; therefore, only full-term COMBO infants were included.

All mother-infant dyads participating in the COMBO Initiative received prenatal care and delivered at the CUIMC-affiliated NewYorkPresbyterian (NYP) Morgan Stanley Children's Hospital (MSCH) or NYP Allen Pavilion Hospital since the onset of the pandemic (first NYC laboring woman diagnosed 3/13/2020 at MSCH). All dyads with a documented SARS-CoV-2 infection during pregnancy (exposed) according to the electronic health record (EHR) were invited to participate and were enrolled during pregnancy or in the first few months postpartum. For each exposed dyad, 1-3 unexposed dyads, defined as the absence of EHR documentation of maternal SARS-CoV-2 infection during pregnancy and at delivery, were matched based on infant sex, GA at birth, mode of delivery, and date of birth (DOB) within a two-week window. Infants included in the historical cohort were recruited from the Well Baby Nursery at MSCH as part of a separate protocol. Study procedures were approved by the CUIMC Institutional Review Board (IRB) for the COMBO cohort and by the New York State Psychiatric Institute IRB for the historical cohort and informed consent was obtained from all participants.

Data at 6-months of age were available for 248 full-term infants enrolled in the pandemic cohort and 
medRxiv preprint doi: https://doi.org/10.1101/2021.07.12.21260365; this version posted July 15, 2021. The copyright holder for this preprint (which was not certified by peer review) is the author/funder, who has granted medRxiv a license to display the preprint in perpetuity. All rights reserved. No reuse allowed without permission.

71 infants enrolled in the historical cohort. Data were excluded from 10 pandemic cohort and 9 historical cohort infants due to completion of the neurodevelopmental assessment outside of the eligibility window. The final sample included data from 300 infants: $\mathrm{n}=238$ in the pandemic cohort $(\mathrm{n}=107$ exposed; $\mathrm{n}=131$ unexposed) and $\mathrm{n}=62$ in the historical cohort.

\section{Determination of SARS-CoV-2 infection status}

NYP's hospital practices during the COVID19 pandemic have been published ${ }^{37}$. Mother-infant separation, which is known to affect neurodevelopmental outcomes ${ }^{38}$, was never implemented. The labor and delivery (L\&D) units of the NYP hospital system implemented universal SARS-CoV-2 testing of all delivering patients by nasopharyngeal PCR on 3/22/2020 and by serological testing for antibodies on 7/20/2020. Additional symptom-based testing occurred throughout pregnancy and results obtained from external testing sites were recorded in the EHR when possible. For each mother with a positive SARS-CoV-2 PCR and/or serology test during pregnancy (defined based on last menstrual period and delivery date) identified by automated EHR extraction, a careful chart review was conducted to determine the date of symptom onset, which was then referenced to infant GA to determine the trimester of in utero exposure. Exact exposure timing was determined for 79 of 107 mothers (74\%) included in this analysis. For 28 (26\%) asymptomatic serology-positive mothers, an exact date of symptom onset could not be determined, so the date with the peak number of SARS-CoV-2 infections during the first wave of the pandemic in NYC (4/6/2020) was used to impute the trimester of exposure. SARS-CoV2 infection severity was categorized as asymptomatic, mild (defined as nonpneumonia or mild pneumonia) or severe (defined as dyspnea, respiratory rate $\geq 30 / \mathrm{min}$, blood oxygen saturation $\leq 93 \%$, partial pressure of arterial oxygen to fraction of inspired oxygen ratio $<300$, and/or lung infiltrates $>50 \%$ within $24-48$ hours $^{16}$ ).

Based on EHR and/or maternal-report, five infants in the pandemic cohort and zero infants in the historical cohort were infected with SARS-CoV-2 between birth and the neurodevelopmental assessment.

\section{Assessment of infant 6-month neurodevelopment}

Between 5 months, 0 days, and 6 months, 30 days (186.79 \pm 11.75 days), infant neurodevelopment was assessed by maternal-report using the Ages \& Stages Questionnaire, $3^{\text {rd }}$ Edition (ASQ-3) in English or Spanish via secure REDCap survey. The ASQ-3 was completed between October, 2020 and June, 2021 for the pandemic cohort and between May, 2018 and July, 2020 for the historical cohort. The ASQ-3 is a validated, widely used, standardized, level 1 screening tool based on parental-report that reliably assesses five key developmental domains: communication, fine and gross motor, problem solving, and personal-social skills. The ASQ-3 has strong concurrent validity $(\mathrm{r}=0.85)$, two-week test-retest reliability $(\mathrm{r}=0.75$ $0.82)$, inter-observer reliability $(\mathrm{r}=0.43-0.69)$, and internal consistency $(\alpha=0.51-0.87)^{39,40}$.

\section{Statistical analyses}

Statistical analyses were conducted in $\mathrm{R}$ version 4.0.2. The experimental design (forced-choice online survey and chart review) resulted in no missingness. Power analyses were based on the primary outcome investigating mean differences in ASQ-3 subdomain scores between infants with and without in utero exposure to maternal SARS-CoV-2 infection using analyses of covariance (ANCOVAs), for which we had $90 \%$ power to detect a 0.5 SD difference in each subdomain using a two-sided test with alpha $<0.05$ (see Supplementary Materials). Within the exposed subset, we also examined the effect of SARS-CoV-2 timing and severity on ASQ-3 subdomains via ANCOVA. For secondary analyses, ANCOVAs were used to determine mean differences in ASQ-3 subdomains between the pandemic and historical cohorts. For both primary and secondary analyses, we implemented minimally (GA at birth, infant sex, and infant age at assessment) and fully adjusted models (additionally controlled for maternal race, ethnicity, age at delivery, educational attainment, parity, and mode of delivery). Percentages of infants screening below cutoffs indicative of delays per ASQ3 developers ${ }^{39}$ were computed for each subdomain and for overall ASQ-3. Fisher's Exact Test was used to examine group differences in screening positive for delays between the pandemic and historical cohorts. For ASQ-3 subdomains where a significant main effect was identified, tertiary analyses examined scores in relation to trimester of pregnancy during peak NYC SARS-CoV-2 cases (4/6/2020) using fully adjusted ANCOVA models with general linear hypothesis testing using Tukey pairwise contrasts. 
medRxiv preprint doi: https://doi.org/10.1101/2021.07.12.21260365; this version posted July 15, 2021. The copyright holder for this preprint (which was not certified by peer review) is the author/funder, who has granted medRxiv a license to display the preprint in perpetuity. All rights reserved. No reuse allowed without permission.

Mean differences with confidence intervals (95\% CI) are reported for all significant main effects. Estimated marginal means are reported in supplemental tables. Significance was set at $\mathrm{p}<0.05$.

\section{Results}

\section{Cohort characteristics}

Highlighting the disproportionate impact of COVID-19 on already medically disadvantaged groups, SARS-CoV-2 infected mothers significantly differed from non-infected mothers in their selfreported race $\left(\mathrm{X}^{2}=18.33, p=0.005\right)$, ethnicity
$\left(\mathrm{X}^{2}=21.07, p<0.001\right), \quad$ and education attainment $\left(\mathrm{X}^{2}=21.80, p=0.001\right)$, with a higher proportion identifying as other or mixed race $(34.6 \%$ versus $21.4 \%$ ) and Hispanic or Latino/a/x or Spanish ethnicity $(64.5 \%$ versus $38.9 \%$ ) and a lower proportion reporting a graduate degree (16.8\% versus $40.5 \%)$ (Table 1). Compared to the pandemic cohort, the historical cohort significantly differed in race $\left(\mathrm{X}^{2}=51.04, p<0.001\right)$, ethnicity $\left(\mathrm{X}^{2}=37.85, p<0.001\right)$, education attainment $\left(\mathrm{X}^{2}=35.17, p<0.001\right)$, and mode of delivery $\left(\mathrm{X}^{2}=16.95, p<0.001\right)$. Group differences were accounted for in all fully adjusted models.

\begin{tabular}{|c|c|c|c|c|c|c|c|c|c|}
\hline \multirow[b]{2}{*}{$\begin{array}{l}\text { Variable } \\
\text { No. (\%) or Median (Min, Max) }\end{array}$} & \multirow[b]{2}{*}{$\begin{array}{l}\text { Overall } \\
\text { Sample } \\
(\mathrm{N}=300)\end{array}$} & \multirow[b]{2}{*}{$\begin{array}{c}\text { SARS-CoV-2 } \\
\text { Unexposed } \\
(\mathrm{N}=131)\end{array}$} & \multirow[b]{2}{*}{$\begin{array}{l}\text { SARS-CoV-2 } \\
\text { Exposed } \\
(\mathrm{N}=107) \\
\end{array}$} & \multicolumn{2}{|c|}{$\begin{array}{c}\text { SARS-CoV-2 Unexposed } \\
\text { vs. Exposed }\end{array}$} & \multirow[b]{2}{*}{$\begin{array}{c}\text { Historical } \\
\text { Cohort } \\
(\mathrm{N}=62)\end{array}$} & \multirow[b]{2}{*}{$\begin{array}{l}\text { Pandemic } \\
\text { Cohort } \\
(n=238) \\
\end{array}$} & \multicolumn{2}{|c|}{$\begin{array}{c}\text { Historical Cohort vs. } \\
\text { Pandemic Cohort }\end{array}$} \\
\hline & & & & $p^{t}$ & $\begin{array}{c}\text { Test } \\
\text { statistic }\end{array}$ & & & $p^{\dagger}$ & $\begin{array}{c}\text { Test } \\
\text { statistic }\end{array}$ \\
\hline \multicolumn{10}{|l|}{ Maternal Characteristics } \\
\hline Age at Delivery (years) & $\begin{array}{c}32.0 \\
(18.0,46.0)\end{array}$ & $\begin{array}{c}32.0 \\
(19.0,45.0)\end{array}$ & $\begin{array}{c}31.0 \\
(19.0,44.0)\end{array}$ & 0.053 & 5987 & $\begin{array}{c}32.0 \\
(18.0,46.0)\end{array}$ & $\begin{array}{c}32.0 \\
(19.0,45.0)\end{array}$ & 0.25 & 6676 \\
\hline Race & & & & 0.005 & 18.33 & & & $<0.001$ & 51.04 \\
\hline Black or African American & $43(14.3)$ & $17(13.0)$ & $14(13.1)$ & & & $12(19.4)$ & $31(13.0)$ & & \\
\hline Native American or Alaskan Native & $6(2.0)$ & $1(0.8)$ & $1(0.9)$ & & & $4(6.5)$ & $2(0.8)$ & & \\
\hline Native Hawaiian or Other Pacific Islander & $3(1.0)$ & $2(1.5)$ & $1(0.9)$ & & & $0(0)$ & $3(1.3)$ & & \\
\hline Asian or Asian American & $17(5.7)$ & $13(9.9)$ & $2(1.9)$ & & & $2(3.2)$ & $15(6.3)$ & & \\
\hline White & $104(34.7)$ & $59(45.0)$ & $32(29.9)$ & & & $13(21.0)$ & $91(38.2)$ & & \\
\hline Other or Mixed Race & $96(32.0)$ & $28(21.4)$ & $37(34.6)$ & & & $31(50.0)$ & $65(27.3)$ & & \\
\hline Declined or Unknown & $31(10.3)$ & $11(8.4)$ & $20(18.7)$ & & & $0(0)$ & $31(13.0)$ & & \\
\hline Ethnicity & & & & $<0.001$ & 21.07 & & & $<0.001$ & 37.85 \\
\hline Hispanic or Latino/a/x or Spanish & $168(56.0)$ & $51(38.9)$ & $69(64.5)$ & & & $48(77.4)$ & $120(50.4)$ & & \\
\hline Not Hispanic or Latino/a/x or Spanish & $115(38.3)$ & $73(55.7)$ & $28(26.2)$ & & & $14(22.6)$ & $101(42.4)$ & & \\
\hline Declined or Unknown & $17(5.7)$ & $7(5.3)$ & $10(9.3)$ & & & $0(0)$ & $17(7.1)$ & & \\
\hline Education Attainment & & & & 0.001 & 21.80 & & & $<0.001$ & 35.17 \\
\hline Some High School & $28(9.3)$ & $8(6.1)$ & $9(8.4)$ & & & $11(17.7)$ & $17(7.1)$ & & \\
\hline High School Degree/GED/Trade School & $43(14.3)$ & $10(7.6)$ & $20(18.7)$ & & & $13(21.0)$ & $30(12.6)$ & & \\
\hline Some College & $30(10.0)$ & $11(8.4)$ & $11(10.3)$ & & & $8(12.9)$ & $22(9.2)$ & & \\
\hline 2-Year College Degree & $33(11.0)$ & $10(7.6)$ & $18(16.8)$ & & & $5(8.1)$ & $28(11.8)$ & & \\
\hline 4-Year College Degree & $79(26.3)$ & $37(28.2)$ & $30(28.0)$ & & & $12(19.4)$ & $67(28.2)$ & & \\
\hline Graduate Degree & $83(27.7)$ & $53(40.5)$ & $18(16.8)$ & & & $12(19.4)$ & $71(29.8)$ & & \\
\hline Declined or Unknown & $4(1.3)$ & $2(1.5)$ & $1(0.9)$ & & & $1(1.6)$ & $3(1.3)$ & & \\
\hline \multicolumn{10}{|l|}{ Infant Characteristics } \\
\hline Vaginal Delivery & $186(62.0)$ & $81(61.8)$ & $79(73.8)$ & 0.068 & 3.32 & $26(41.9)$ & $160(67.2)$ & $<0.001$ & 16.95 \\
\hline Primiparous & $142(47.3)$ & $70(53.4)$ & $49(45.8)$ & 0.30 & 1.09 & $23(37.1)$ & $119(50.0)$ & 0.30 & 1.09 \\
\hline Gestational Age at Birth (weeks) & $\begin{array}{l}39.1(37.0 \\
41.6)\end{array}$ & $\begin{array}{l}39.1(37.0 \\
41.6)\end{array}$ & $\begin{array}{l}39.1(37.0 \\
41.1)\end{array}$ & 0.46 & 7396 & $\begin{array}{l}39.1(37.0 \\
41.0)\end{array}$ & $\begin{array}{c}39.1(37.0 \\
41.6)\end{array}$ & 0.17 & 8211 \\
\hline Female Sex & $129(43.0)$ & $49(37.4)$ & $54(50.5)$ & 0.059 & 3.58 & $26(41.9)$ & $103(43.3)$ & 0.13 & 4.14 \\
\hline
\end{tabular}

tComparisons performed using Chi Squared Test for binomial variables and Wilcoxon Rank-Sum test for continuous variables.

All statistical tests were two-sided.

\section{Maternal SARS-CoV-2 infection during pregnancy is not associated with differences in ASQ-3 scores at 6-months}

There were no significant group differences between exposed and unexposed infants in any of the five ASQ-3 subdomain scores (communication, gross motor, fine motor, problem solving, or personal- social) at 6-months (Figure 1A) in either minimally or fully adjusted models (Table 2). The majority of mothers experienced asymptomatic $(36 \%)$ or mild disease $(61 \%)$ and were infected in the second $(48 \%)$ or third (33\%) trimester (Supplemental Table S1). A small proportion of mothers had severe disease (4\%) and $20 \%$ were infected in the first trimester. Neither 
medRxiv preprint doi: https://doi.org/10.1101/2021.07.12.21260365; this version posted July 15, 2021. The copyright holder for this preprint (which was not certified by peer review) is the author/funder, who has granted medRxiv a license to display the preprint in perpetuity. All rights reserved. No reuse allowed without permission.

symptom severity nor timing of infection showed an association to any ASQ-3 subdomain score in either minimally or fully adjusted models (Supplemental Table S2 and S3).

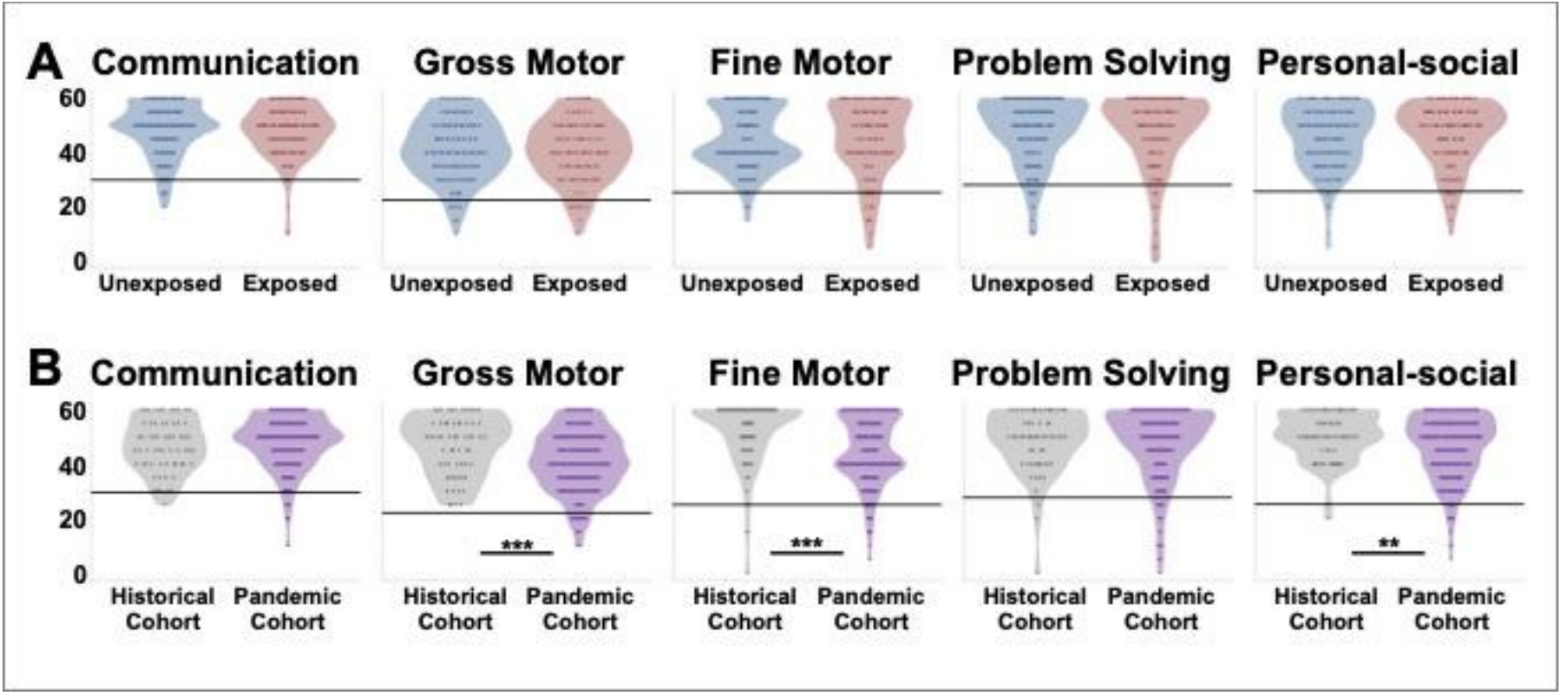

Figure 1. ASQ-3 scores at 6-months of age. (A) Total raw scores on each ASQ-3 domain for infants with in utero exposure to maternal SARSCoV-2 infection (red) versus unexposed infants (blue). No significant group differences were identified on any of the ASQ-3 domains in either minimally or fully adjusted models. (B) Total raw scores on each ASQ-3 domain for infants born during the pandemic (purple) versus a historical cohort (gray) born at the same hospital. Gray horizontal lines represent the cutoff indicating possible delay on each subscale $($ communication $=$ 29.65 ; gross motor $=22.25$; fine motor $=25.14$; problem solving $=27.72$; personal-social $=25.34) *{ }^{*}<<0.05, * * p<0.01, * * * p<0.001$, on fully adjusted models.

Birth during the pandemic is associated with lower ASQ-3 scores in several domains at 6-months

Our primary analysis revealed no associations between SARS-CoV-2 status, timing, or severity and ASQ-3 scores. Therefore, exposed and unexposed infants in the pandemic cohort were pooled together and compared to infants in the historical cohort. Compared to those in the historical cohort, infants in the pandemic cohort had significantly lower mean scores on the gross motor (mean difference $-5.68,95 \%$ CI $[-8.80,-2.56], \mathrm{F}_{1}$, $295=12.83, p=0.0003, \mathrm{n}^{2}=0.016$ ), fine motor (mean difference $-6.77,95 \%$ CI $[-10.21,-3.33], \quad F_{1}$, $\left.295=15.00, p=0.0001, \mathrm{n}^{2}=0.017\right)$, and personal-social (mean difference $-4.21,95 \%$ CI $[-7.23,-1.20], \mathrm{F}_{1}$, $\left.295=7.60, p=0.006, \mathrm{n}^{2}=0.008\right)$ subdomains in the minimally adjusted models (Figure 1B, Table 2, Supplemental Table S4). These group differences persisted in the fully adjusted model (gross motor: (mean difference $-5.68,95 \%$ CI [-8.82, -2.53], $\mathrm{F}_{1}$, $278=12.63, p=0.0004, \mathrm{n}^{2}=0.008$ ), fine motor: (mean difference $-6.77,95 \%$ CI $[-10.16,-3.37], \quad F_{1}$, 278=15.39, $\left.p=0.0001, \mathrm{n}^{2}=0.011\right)$, personal-social: (mean difference $-4.21,95 \%$ CI [-7.23, -1.20], $\mathrm{F}_{1}$, $\left.\left.278=7.60, p=0.006, \mathrm{n}^{2}=0.005\right)\right)$. Sensitivity analyses excluding five infants diagnosed with COVID-19 between birth and ASQ-3 assessments did not alter findings (Supplemental Table S5 and S6). Sensitivity analyses excluding 15 infants in the historical cohort who were assessed during the pandemic did not alter findings on fine and gross motor scores, but personal-social scores no longer differed significantly between cohorts (Supplemental Table S7).

Though not specifically powered to detect differences in the proportion of infants who met screening cutoffs for delay, a greater proportion of infants in the pandemic cohort met the gross motor cutoff (one-sided Fisher's, $p=0.01$ ) (Table 2).

First trimester of pregnancy during the height of the pandemic is associated with lowest ASQ-3 personal-social scores at 6-months

We investigated whether the timing of pregnancy relative to the peak of the pandemic in NYC was associated with scores on the ASQ-3 subdomains that were identified as different between the pandemic and historical cohorts using fully adjusted models. There was a significant effect of trimester of pregnancy on fine motor $\left(\mathrm{F}_{3}, 277=6.04\right.$, $\left.p=0.0005, \mathrm{n}^{2}=0.016\right)$ and gross motor scores $\left(\mathrm{F}_{3}\right.$, $\left.277=5.34, p=0.001, \mathrm{n}^{2}=0.012\right)$. However, Tukey 
medRxiv preprint doi: https://doi.org/10.1101/2021.07.12.21260365; this version posted July 15, 2021. The copyright holder for this preprint (which was not certified by peer review) is the author/funder, who has granted medRxiv a license to display the preprint in perpetuity. All rights reserved. No reuse allowed without permission.

contrasts did not reach the significance threshold ( $p>.05)$ (Supplemental Table S8 and S9). There was also a significant effect of trimester of pregnancy on infant personal-social scores $\left(\mathrm{F}_{3}, 277=4.05, p=0.007\right.$, $\left.\mathrm{n}^{2}=0.025\right)$. Compared to historic controls, infants born to mothers who were in their first trimester of pregnancy during the peak of the pandemic had a significant reduction in personal-social scores (mean difference $-6.16,95 \%$ CI $[-12.22,-0.10], p=0.009$ ) (Figure 2, Supplemental Table S8 and S10).

\begin{tabular}{|c|c|c|c|c|c|c|c|c|c|c|c|c|c|}
\hline \multirow[b]{3}{*}{ ASQ-3 Subdomain } & \multirow[b]{3}{*}{$\begin{array}{l}\text { Overall } \\
\text { Sample } \\
(\mathrm{N}=300)\end{array}$} & \multirow[b]{3}{*}{$\begin{array}{l}\text { Unexposed } \\
(N=131)\end{array}$} & \multirow[b]{3}{*}{$\begin{array}{l}\text { Exposed } \\
(\mathrm{N}=107)\end{array}$} & \multicolumn{4}{|c|}{$\begin{array}{l}\text { SARS-CoV-2 Unexposed vs. } \\
\text { Exposed }\end{array}$} & \multirow[b]{3}{*}{$\begin{array}{l}\text { Historical } \\
\text { Cohort } \\
(\mathrm{N}=62)\end{array}$} & \multirow[b]{3}{*}{$\begin{array}{c}\text { Pandemic } \\
\text { Cohort } \\
(\mathrm{N}=238)\end{array}$} & \multirow{2}{*}{\multicolumn{4}{|c|}{$\begin{array}{cc}\text { Historical Cohort vs. Pandemic Cohort } \\
\text { Minimally } & \text { Fully } \\
\text { Adjusted } & \text { Adjusted } \\
\end{array}$}} \\
\hline & & & & \multicolumn{2}{|c|}{$\begin{array}{l}\text { Minimally } \\
\text { Adjusted } \\
\end{array}$} & \multicolumn{2}{|c|}{$\begin{array}{c}\text { Fully } \\
\text { Adjusted } \\
\end{array}$} & & & & & & \\
\hline & & & & $F(D F)$ & $p$ & $F(D F)$ & $p$ & & & $F(D F)$ & $p$ & $F(D F)$ & $p$ \\
\hline \multicolumn{14}{|l|}{ Mean Score (SD) } \\
\hline Communication & $47.7(9.70)$ & $48.1(9.76)$ & 47.7 (9.77) & $\begin{array}{c}0.07 \\
(1,233)\end{array}$ & 0.78 & $\begin{array}{c}0.07 \\
(1,216)\end{array}$ & 0.78 & $46.8(9.54)$ & $47.9(9.74)$ & $\begin{array}{c}0.66 \\
(1,295)\end{array}$ & 0.41 & $\begin{array}{c}0.68 \\
(1,278)\end{array}$ & 0.41 \\
\hline Gross Motor & $42.3(11.6)$ & $41.5(11.4)$ & 40.7 (11.8) & $\begin{array}{c}0.29 \\
(1,233)\end{array}$ & 0.58 & $\begin{array}{c}0.29 \\
(1,216)\end{array}$ & 0.58 & $46.8(10.8)$ & 41.1 (11.6) & $\begin{array}{c}12.83 \\
(1,295)\end{array}$ & $<0.001$ & $\begin{array}{c}12.63 \\
(1,278)\end{array}$ & $<0.001$ \\
\hline Fine Motor & $46.5(12.7)$ & $45.0(11.1)$ & $45.1(14.0)$ & $\begin{array}{c}0.004 \\
(1,233)\end{array}$ & 0.94 & $\begin{array}{c}0.004 \\
(1,216)\end{array}$ & 0.94 & $51.9(12.1)$ & $45.1(12.5)$ & $\begin{array}{c}15.00 \\
(1,295)\end{array}$ & $<0.001$ & $\begin{array}{c}15.39 \\
(1,278)\end{array}$ & $<0.001$ \\
\hline Problem Solving & $47.8(13.0)$ & $47.8(12.3)$ & $47.3(14.5)$ & $\begin{array}{c}0.07 \\
(1,233)\end{array}$ & 0.78 & $\begin{array}{c}0.07 \\
(1,216)\end{array}$ & 0.78 & $48.6(11.6)$ & $47.6(13.3)$ & $\begin{array}{c}0.33 \\
(1,295)\end{array}$ & 0.56 & $\begin{array}{c}0.33 \\
(1,278)\end{array}$ & 0.56 \\
\hline Personal-Social & $47.2(11.2)$ & $46.0(11.5)$ & $46.7(11.6)$ & $\begin{array}{c}0.23 \\
(1,233)\end{array}$ & 0.62 & $\begin{array}{c}0.24 \\
(1,216)\end{array}$ & 0.62 & $50.6(8.78)$ & $46.3(11.6)$ & $\begin{array}{c}7.60 \\
(1,295)\end{array}$ & 0.006 & $\begin{array}{c}7.60 \\
(1,278)\end{array}$ & 0.006 \\
\hline Below Cutoff (\%) & & & & & & & & & & \multicolumn{2}{|c|}{$\begin{array}{l}\text { Fisher's Exact } \\
\text { Test }^{\dagger} p \\
\end{array}$} & & \\
\hline Communication & $10(3.3)$ & $6(4.6)$ & $3(2.8)$ & & & & & $1(1.6)$ & $9(3.8)$ & & & & \\
\hline Gross Motor & $18(6.0)$ & $8(6.1)$ & $10(9.3)$ & & & & & $0(0)$ & $18(7.6)$ & & & & \\
\hline Fine Motor & $22(7.3)$ & $5(3.8)$ & $14(13.1)$ & & & & & $3(4.8)$ & $19(8.0)$ & & & & \\
\hline Problem Solving & $23(7.7)$ & $10(7.6)$ & $10(9.3)$ & & & & & $3(4.8)$ & $20(8.4)$ & & & & \\
\hline Personal-Social & $16(5.3)$ & $6(4.6)$ & $8(7.5)$ & & & & & $2(3.2)$ & $14(5.9)$ & & & & \\
\hline Any domain & $53(17.7)$ & $22(16.8)$ & $24(22.4)$ & & & & & $7(11.3)$ & $46(19.3)$ & & & & \\
\hline
\end{tabular}

\section{Discussion}

The clinical and research communities have emphasized the critical need for information regarding the neurodevelopmental effects of fetal exposure to maternal SARS-CoV-2 infection ${ }^{27-31}$. Prior studies of the association between fetal exposure to maternal viral infections, MIA, and atypical child neurodevelopment, led to the speculation that maternal SARS-CoV-2 infection during pregnancy may be associated with global developmental delays or specific neurodevelopmental disorders ${ }^{27-31}$. To our knowledge, our analysis is the first to examine this association and, contrary to the proposed hypothesis, we did not find an association between maternal SARS-CoV-2 infection status, timing, or severity and infant neurodevelopment at 6-months of age as measured using a standardized screener. However, infants born during the pandemic, regardless of maternal SARS-CoV-2 status, scored significantly lower on the gross motor, fine motor, and personalsocial subdomains of the ASQ-3 when compared to a historical cohort of infants born at the same institution at least two months prior to the start of the pandemic. Furthermore, early gestation at the peak of the pandemic in NYC was associated with lowest personal-social scores compared to historic controls. Taken together, these findings suggest the potential for a significant public health impact on the generation born during the COVID-19 pandemic, necessitating further investigation.

Despite little evidence that coronaviruses, such as SARS-CoV, MERS-CoV, and now SARSCoV-2, can cross the placenta ${ }^{41,42}$, the speculation that in utero SARS-CoV-2 exposure may impact infant neurobehavior was based on the established role of MIA on fetal brain development and fueled by recent findings of increased interleukin-6 (IL-6) in SARS-CoV-2-infected pregnant women ${ }^{43}$. In animal models of MIA, both viral exposure and direct injection of IL-6 lead to dose-dependent atypical behavior in offspring ${ }^{44,45}$. Although SARSCoV-2 severity during pregnancy is positively correlated with IL-6 levels ${ }^{43}$, our analysis did not reveal an association between severity and ASQ-3 scores. It should be noted that the majority of our 


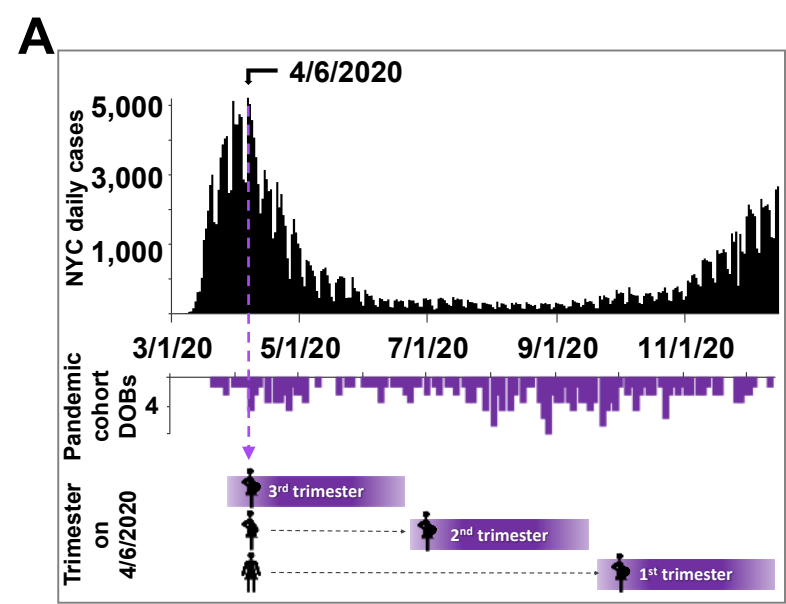

B
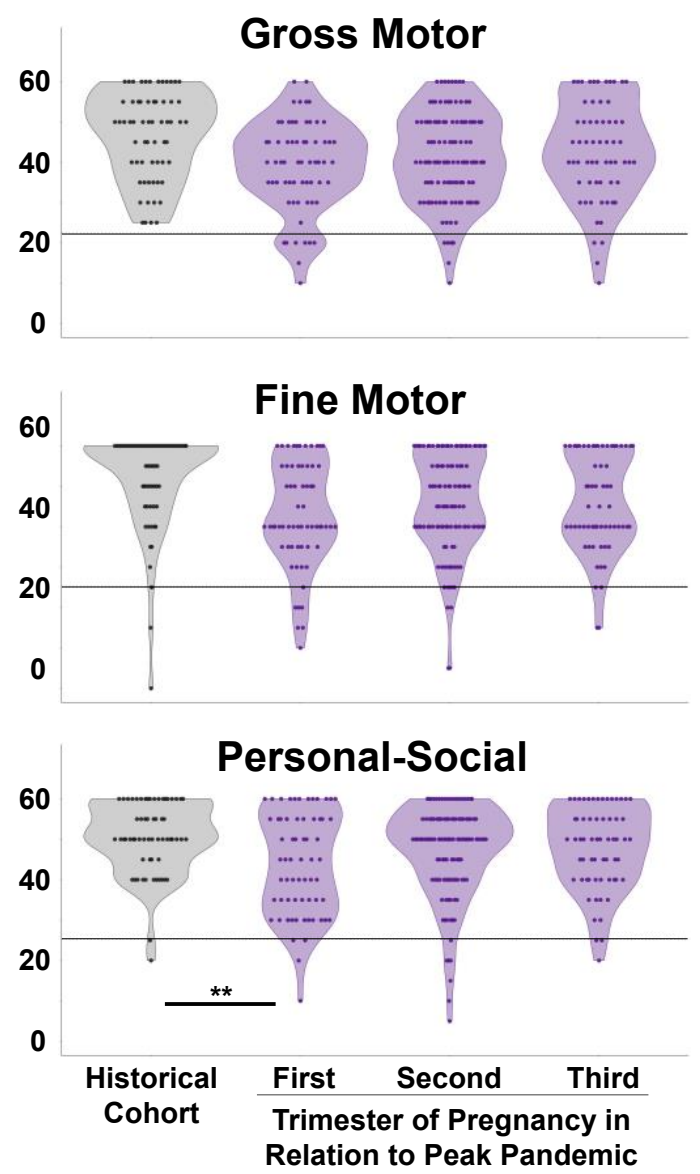

Figure 2. Relationship between trimester of pregnancy during the pandemic peak and ASQ-3 subdomain scores at 6-months of age. (A) The histogram in black represents the number of recorded daily SARS-CoV-2 positive cases in NYC between March and December, 2020. The histogram in purple represents the dates of birth in two-day bins of infants enrolled in the pandemic cohort. The diagram below depicts the trimester of pregnancy corresponding to the dates of birth in the purple histogram in relation to the peak of the COVID-19 pandemic in NYC (April $6^{\text {th }}$, 2020). (B) ASQ-3 gross motor, fine motor, and personal-social scores for infants in the historical cohort versus infants in the pandemic cohort by maternal trimester of pregnancy at the peak of the pandemic in NYC (April $\left.6^{\text {th }}, 2020\right)$. Gray horizontal lines represent the cutoff indicating possible delay on each subscale $($ gross motor $=22.25$; fine motor $=25.14$; personal -social $=25.34)$. ${ }^{*} \mathrm{p}<0.05, * * \mathrm{p}<0.01, * * * \mathrm{p}<0.001$, on fully adjusted model. participants experienced an asymptomatic or mild SARS-CoV-2 infection, and therefore, infants exposed to significant MIA may not be represented in our data. Similarly, early gestational exposure is most likely to be associated with adverse neurodevelopmental outcomes ${ }^{46-48}$. Given that only 21 maternal SARS-Cov-2 infections (8 imputed) in our sample occurred in the first trimester, our results provide limited power for detecting the effects of infection at this early timepoint.

Together, the lack of neurodevelopmental differences between in utero SARS-CoV-2 exposed and unexposed infants and the observed group differences between the historical and pandemic cohorts suggest COVID-19-related stress should be considered as a potential underlying mechanism. Reported stressors have included job loss, food insecurity, and loss of housing, ${ }^{49}$ and the pandemic has resulted in significant increases in symptoms of anxiety and depression ${ }^{50}$. Consistent with our finding that infants born to women who were in the first trimester of pregnancy during the pandemic peak had the greatest reduction in personal-social scores, data from numerous cohort studies have demonstrated that prenatal perceived stress, loneliness, and objective stress, especially during early gestation, are associated with increased risk for adverse neurodevelopment in children ${ }^{3,51-59}$.

Although consistent with prior studies of children born during natural disasters, interpretation of our results should take into account several limitations. The data included in this analysis represent a single center, which may impact generalizability. Critically, it is also possible that developmental outcomes beyond 6-months of age will show different patterns as this is a relatively early timepoint. The ASQ-3 has modest agreement with objective measures of development ${ }^{60,61}$ and is often used by general pediatricians ${ }^{62}$. However, as a parent-report measure, our results may reflect parental-perception of - rather than objective differences in - infant neurodevelopment. Nonetheless, parental perception of development also has implications for long-term child outcomes ${ }^{63}$. Notable strengths of our study include detailed medical records on maternal SARS-CoV-2 status, timing, and severity, and availability of a historical comparison group from the same hospital center using the same neurodevelopmental assessment.

This first analysis of the neurodevelopment of infants born during the COVID-19 pandemic 
supports the critical need for long-term monitoring of these children to mitigate the substantial sequelae observed in generations born during previous pandemics.

\section{Funding}

This study was supported by R01 MH126531 awarded to Drs. Dumitriu, Monk, and Marsh, gift funding from Einhorn Collaborative to Dr. Welch, P2CHD058486 awarded to Drs. Fifer, Alcántara, and Zork through the Columbia Population Research Center from the Eunice Kennedy Shriver National Institute of Child Health \& Human Development, an award to Dr. Shuffrey from the Rita G. Rudel Foundation, and an early career award to Dr. Firestein from the Society for Research in Child Development.

\section{Conflicts of Interest}

Drs. Gyamfi-Bannerman, Dumitriu, Stockwell, and Mourad receive funding from the Centers for Disease Control and Prevention for COVID-19-related mother-infant research. Drs. Gyamfi-Bannerman and Dumitriu have pending reimbursement for consulting for Medela Inc.

\section{References}

1. Sutton D, Fuchs K, D'Alton M, Goffman D. Universal Screening for SARS-CoV-2 in Women Admitted for Delivery. The New England journal of medicine 2020;382:2163-4.

2. Tau GZ, Peterson BS. Normal development of brain circuits. Neuropsychopharmacology 2010;35:147-68.

3. Monk C, Lugo-Candelas C, Trumpff C. Prenatal Developmental Origins of Future Psychopathology: Mechanisms and Pathways. Annu Rev Clin Psychol 2019;15:317-44.

4. Goldstein JA, Norris SA, Aronoff DM. $\mathrm{DOHaD}$ at the intersection of maternal immune activation and maternal metabolic stress: a scoping review. J Dev Orig Health Dis 2017;8:273-83. 5. Bailey R, Kamenga M, Nsuami M, Nieburg $\mathrm{P}$, St Louis M. Growth of children according to maternal and child HIV, immunological and disease

\section{Acknowledgements}

The authors are grateful for the institutional support provided by the Maternal-Child Research Oversight (MaCRO) Committee and the Departments of Pediatrics, Psychiatry, and Obstetrics and Gynecology at Columbia University Irving Medical Center, which made possible the collection of timesensitive information at the height of the COVID-19 pandemic prior to the availability of external funding opportunities. The authors wish to thank the entire COVID-19 Mother Baby Outcomes (COMBO) Initiative Team for their incredible collaborative and persevering contributions during uncertain times. Finally, the authors extend particular gratitude toward the families enrolled in COMBO, whose participation continues to inform our understanding of this unprecedented global event.

characteristics: A prospective cohort study in Kinshasa, Democratic Republic of Congo. International journal of epidemiology 1999;28:53240.

6. Boivin M, Maliwichi-Senganimalunje L, Ogwang L, et al. Neurodevelopmental effects of ante-partum and post-partum antiretroviral exposure in HIV-exposed and uninfected children versus HIV-unexposed and uninfected children in Uganda and Malawi: a prospective cohort study. The Lancet HIV 2019;6.

7. Cassidy AR, Williams PL, Leidner J, et al. In Utero Efavirenz Exposure and

Neurodevelopmental Outcomes in HIV-exposed Uninfected Children in Botswana. The Pediatric infectious disease journal 2019;38:828-34.

8. Evans C, Jones C, Prendergast A. HIVexposed, uninfected infants: New global challenges 
medRxiv preprint doi: https://doi.org/10.1101/2021.07.12.21260365; this version posted July 15, 2021. The copyright holder for this preprint (which was not certified by peer review) is the author/funder, who has granted medRxiv a license to display the preprint in perpetuity. All rights reserved. No reuse allowed without permission.

in the era of paediatric HIV elimination. The Lancet Infectious Diseases 2016;16.

9. le Roux SM, Donald KA, Kroon M, et al. HIV Viremia During Pregnancy and

Neurodevelopment of HIV-Exposed Uninfected

Children in the Context of Universal Antiretroviral Therapy and Breastfeeding: A Prospective Study. Pediatr Infect Dis J 2019;38:70-5.

10. Omoni AO, Ntozini R, Evans C, et al. Child Growth According to Maternal and Child HIV Status in Zimbabwe. The Pediatric infectious disease journal 2017;36:869-76.

11. Powis KM, Slogrove AL, Okorafor I, et al. Maternal Perinatal HIV Infection Is Associated With Increased Infectious Morbidity in HIVexposed Uninfected Infants. The Pediatric infectious disease journal 2019;38:500-2.

12. Springer P, Slogrove A, Kidd M, et al. Neurodevelopmental and behavioural outcomes of HIV-exposed uninfected and HIV-unexposed children at 2-3 years of age in Cape Town, South Africa. AIDS Care 2019;32:1-9.

13. Strehlau R, Aswegen T, Burke M, Kuhn L, Potterton J. A description of early neurodevelopment in a cohort of HIV-exposed uninfected children. AIDS Care 2020:1-8.

14. Wedderburn C, Yeung S, Rehman A, et al. Neurodevelopment of HIV-exposed uninfected children in South Africa: outcomes from an observational birth cohort study. The Lancet Child \& Adolescent Health 2019;3.

15. Wedderburn CJ, Evans C, Yeung S, Gibb DM, Donald KA, Prendergast AJ. Growth and Neurodevelopment of HIV-Exposed Uninfected Children: a Conceptual Framework. Curr HIV/AIDS Rep 2019;16:501-13.

16. Dumitriu D, Emeruwa UN, Hanft E, et al. Outcomes of Neonates Born to Mothers With

Severe Acute Respiratory Syndrome Coronavirus 2 Infection at a Large Medical Center in New York City. JAMA Pediatrics 2020.

17. Kyle MH, Glassman ME, Khan A, et al. A review of newborn outcomes during the COVID-19 pandemic. Semin Perinatol 2020:151286.

18. Breslin N, Baptiste C, Gyamfi-Bannerman $\mathrm{C}$, et al. Coronavirus disease 2019 infection among asymptomatic and symptomatic pregnant women: two weeks of confirmed presentations to an affiliated pair of New York City hospitals. American Journal of Obstetrics \& Gynecology MFM 2020;2:100118.
19. Di Mascio D, Khalil A, Saccone G, et al. Outcome of Coronavirus spectrum infections (SARS, MERS, COVID 1 -19) during pregnancy: a systematic review and meta-analysis. American journal of obstetrics \& gynecology MFM 2020;2:100107-.

20. Salvatore CM, Han J-Y, Acker KP, et al. Neonatal management and outcomes during the COVID-19 pandemic: an observation cohort study. The Lancet Child \& Adolescent Health 2020.

21. Yin M, Zhang L, Deng G, et al. Severe Acute Respiratory Syndrome Coronavirus 2 (SARS-CoV-2) Infection During Pregnancy In China: A Retrospective Cohort Study. medRxiv 2020:2020.04.07.20053744.

22. Boulanger-Bertolus J, Pancaro C, Mashour GA. Increasing Role of Maternal Immune Activation in Neurodevelopmental Disorders. Frontiers in Behavioral Neuroscience 2018;12.

23. Ferguson G, Jelsma J. The prevalence of motor delay among HIV infected children living in Cape Town, South Africa. Int J Rehabil Res 2009;32:108-14.

24. Almond D. Is the 1918 Influenza Pandemic Over? Long-Term Effects of In Utero Influenza Exposure in the Post-1940 U.S. Population. Journal of Political Economy 2006;114:672-712.

25. Sakurada K, Noda Y. Neurodevelopmental Disorders Induced by Maternal Immune Activation: Toward a Prevention Strategy in the Era of the COVID-19 Pandemic. Psychiatry International 2020;1.

26. Patterson PH. Immune involvement in schizophrenia and autism: etiology, pathology and animal models. Behav Brain Res 2009;204:313-21. 27. Martins-Filho PR, Tanajura DM, Santos HP, Jr., Santos VS. COVID-19 during pregnancy: Potential risk for neurodevelopmental disorders in neonates? European journal of obstetrics, gynecology, and reproductive biology 2020;250:255-6.

28. López-Díaz Á, Ayesa-Arriola R, CrespoFacorro B, Ruiz-Veguilla M. COVID-19 Infection During Pregnancy and Risk of Neurodevelopmental Disorders in Offspring: Time for Collaborative Research. Biological psychiatry 2021;89:e29-e30. 29. Sadeghi MR. Does Lack of Vertical Transmission of COVID-19 Guarantee the Health of the Fetus or Neonate in Infected Mothers? J Reprod Infertil 2020;21:229-30. 
medRxiv preprint doi: https://doi.org/10.1101/2021.07.12.21260365; this version posted July 15, 2021. The copyright holder for this preprint (which was not certified by peer review) is the author/funder, who has granted medRxiv a license to display the preprint in perpetuity. All rights reserved. No reuse allowed without permission.

30. Ahmed WN, Noushin AM, Shafjeer A, Ann R. COVID-19 and Pregnancy: Time to Think beyond Medications. Pan Asian Journal of Obstetrics \& Gynecology 2020;3:82-92.

31. Okechukwu C. Inflammatory cytokines induced by severe acute respiratory syndrome coronavirus 2 infection during pregnancy may alter fetal brain development predisposing the offspring to neurodevelopmental disorders. Nigerian Journal of Experimental and Clinical Biosciences 2021;9:58.

32. Finlay-Jones A, Varcin K, Leonard H, Bosco A, Alvares G, Downs J. Very Early Identification and Intervention for Infants at Risk of Neurodevelopmental Disorders: A Transdiagnostic Approach. Child Development Perspectives 2019;13:97-103.

33. Landa RJ. Efficacy of early interventions for infants and young children with, and at risk for, autism spectrum disorders. Int Rev Psychiatry 2018;30:25-39.

34. Fernell E, Eriksson MA, Gillberg C. Early diagnosis of autism and impact on prognosis: a narrative review. Clin Epidemiol 2013;5:33-43. 35. Bedford R, Pickles A, Lord C. Early gross motor skills predict the subsequent development of language in children with autism spectrum disorder. Autism Res 2016;9:993-1001.

36. Iverson JM, Shic F, Wall CA, et al. Early motor abilities in infants at heightened versus low risk for ASD: A Baby Siblings Research Consortium (BSRC) study. J Abnorm Psychol 2019;128:69-80.

37. Saiman L, Acker KP, Dumitru D, et al. Infection prevention and control for labor and delivery, well baby nurseries, and neonatal intensive care units. Semin Perinatol 2020;44:151320-.

38. Wang Y, Chen L, Wu T, et al. Impact of Covid-19 in pregnancy on mother's psychological status and infant's neurobehavioral development: a longitudinal cohort study in China. BMC Medicine 2020;18:347.

39. Squires J, Twombly E, Bricker D, Potter L. (ASQ-3) Ages \& Stages Questionnaires, Third Edition. Baltimore, MD: Brookes Publishing; 2009. 40. Blackwell CK, Wakschlag LS, Gershon RC, Cella D. Measurement framework for the

Environmental influences on Child Health Outcomes research program. Curr Opin Pediatr 2018;30:276-84.
41. Schwartz DA, Graham AL. Potential Maternal and Infant Outcomes from (Wuhan) Coronavirus 2019-nCoV Infecting Pregnant Women: Lessons from SARS, MERS, and Other Human Coronavirus Infections. Viruses 2020;12:194.

42. Mahyuddin AP, Kanneganti A, Wong JJL, et al. Mechanisms and evidence of vertical transmission of infections in pregnancy including SARS-CoV-2s. Prenatal diagnosis 2020;40:165570.

43. Tanacan A, Yazihan N, Erol SA, et al. The impact of COVID-19 infection on the cytokine profile of pregnant women: A prospective casecontrol study. Cytokine 2021;140:155431.

44. Solek CM, Farooqi N, Verly M, Lim TK, Ruthazer ES. Maternal immune activation in neurodevelopmental disorders. Dev Dyn 2018;247:588-619.

45. Smith SE, Li J, Garbett K, Mirnics K, Patterson PH. Maternal immune activation alters fetal brain development through interleukin-6. J Neurosci 2007;27:10695-702.

46. Cordeiro CN, Tsimis M, Burd I. Infections and Brain Development. Obstet Gynecol Surv 2015;70:644-55.

47. Khandaker GM, Zimbron J, Lewis G, Jones PB. Prenatal maternal infection, neurodevelopment and adult schizophrenia: a systematic review of population-based studies. Psychol Med 2013;43:239-57.

48. Fitzgerald E, Hor K, Drake AJ. Maternal influences on fetal brain development: The role of nutrition, infection and stress, and the potential for intergenerational consequences. Early human development 2020;150:105190-.

49. Mental Health Impact of the COVID-19 Pandemic: An Update. Kaiser Family Foundation, 2021. (Accessed 5/30/21, at

https://www.kff.org/coronavirus-covid-19/pollfinding/mental-health-impact-of-the-covid-19pandemic.)

50. Vahratian A, Blumberg SJ, Terlizzi EP, Schiller JS. Symptoms of Anxiety or Depressive Disorder and Use of Mental Health Care Among Adults During the COVID-19 Pandemic - United States, August 2020-February 2021. MMWR Morb Mortal Wkly Rep 2021;70:490-4.

51. O'Donnell KJ, Glover V, Barker ED, O'Connor TG. The persisting effect of maternal mood in pregnancy on childhood psychopathology. 
medRxiv preprint doi: https://doi.org/10.1101/2021.07.12.21260365; this version posted July 15, 2021. The copyright holder for this preprint (which was not certified by peer review) is the author/funder, who has granted medRxiv a license to display the preprint in perpetuity. All rights reserved. No reuse allowed without permission.

Development and psychopathology 2014;26:393403.

52. Van den Bergh BRH, van den Heuvel MI, Lahti M, et al. Prenatal developmental origins of behavior and mental health: The influence of maternal stress in pregnancy. Neurosci Biobehav Rev 2020;117:26-64.

53. Guo C, Chen G, He P, Zhang L, Zheng X. Risk of cognitive impairment in children after maternal exposure to the 1998 Yangtze River flood during pregnancy: analysis of data from China's second National Sample Survey on Disability. The Lancet Planetary Health 2020;4:e522-e9.

54. Luoma I, Korhonen M, Puura K, Salmelin RK. Maternal loneliness: concurrent and longitudinal associations with depressive symptoms and child adjustment. Psychol Health Med 2019;24:667-79.

55. Buitelaar JK, Huizink AC, Mulder EJ, de Medina PG, Visser GH. Prenatal stress and cognitive development and temperament in infants. Neurobiol Aging 2003;24 Suppl 1:S53-60; discussion S7-8.

56. Selemon LD, Zecevic N. Schizophrenia: a tale of two critical periods for prefrontal cortical development. Transl Psychiatry 2015;5:e623-e. 57. Khashan AS, Abel KM, McNamee R, et al. Higher risk of offspring schizophrenia following antenatal maternal exposure to severe adverse life events. Arch Gen Psychiatry 2008;65:146-52. 58. Caparros-Gonzalez RA, Torre-Luque A, Romero-Gonzalez B, Quesada-Soto JM, Alderdice F, Peralta-Ramírez MI. Stress During Pregnancy and the Development of Diseases in the offspring: A Systematic-Review and Meta-Analysis. Midwifery 2021;97:102939.

59. Walder DJ, Laplante DP, Sousa-Pires A, Veru F, Brunet A, King S. Prenatal maternal stress predicts autism traits in 61/2 year-old children: Project Ice Storm. Psychiatry Res 2014;219:353-60. 60. Schonhaut L, Armijo I, Schönstedt M, Alvarez J, Cordero M. Validity of the ages and stages questionnaires in term and preterm infants. Pediatrics 2013;131:e1468-74.

61. Sheldrick RC, Marakovitz S, Garfinkel D, Carter AS, Perrin EC. Comparative Accuracy of Developmental Screening Questionnaires. JAMA Pediatr 2020;174:366-74.

62. Lipkin PH, Macias MM. Promoting Optimal Development: Identifying Infants and Young Children With Developmental Disorders Through Developmental Surveillance and Screening. Pediatrics 2020;145:e20193449.

63. Araújo LA, Veloso CF, Souza MC, Azevedo JMC, Tarro G. The potential impact of the COVID19 pandemic on child growth and development: a systematic review. J Pediatr (Rio J) 2020. 
medRxiv preprint doi: https://doi.org/10.1101/2021.07.12.21260365; this version posted July 15, 2021. The copyright holder for this preprint (which was not certified by peer review) is the author/funder, who has granted medRxiv a license to display the preprint in perpetuity.

All rights reserved. No reuse allowed without permission.

\section{SUPPLEMENTAL APPENDIX}

\section{Power analyses}

Our power analyses were based on our primary outcome, which aimed to investigate mean ASQ-3 subdomain score differences between infants with and without in utero exposure to maternal SARS-CoV-2 infections. The developers of the ASQ-3 recommend referral for infants and children scoring less than or equal to 2.0 standard deviations (SD) below normative means on any of the five subdomains. They further recommend monitoring and possible referral for infants and children scoring between 1.0 and 2.0 SD below normative means. Based on their published data, 6-month normative values are (mean $\pm \mathrm{SD}): 48.90 \pm 9.63$ for communication, $45.64 \pm 11.69$ for gross motor, $48.93 \pm 11.90$ for fine motor, $50.41 \pm 11.30$ for problem solving and $48.31 \pm 11.48$ for personal-social. Using these normative values, our power analysis aimed to ensure $90 \%$ power to detect a $0.5 \mathrm{SD}$ difference between groups, with alpha set to $<0.05$. Given COMBO's enrollment has an approximate 1:1 ratio, achieving this requires a sample size of a minimum of 166 infants for problem solving and a minimum of 168 infants for all other subdomains. The current manuscript includes a total of $238 \mathrm{COMBO}$ infants and therefore our analyses were well-powered to detect differences in mean ASQ-3 subdomain scores of at least 0.5 SD between SARS-CoV-2 exposed versus unexposed infants. 
medRxiv preprint doi: https://doi.org/10.1101/2021.07.12.21260365; this version posted July 15, 2021. The copyright holder for this preprint (which was not certified by peer review) is the author/funder, who has granted medRxiv a license to display the preprint in perpetuity.

All rights reserved. No reuse allowed without permission.

Table S1. Maternal SARS-CoV-2 timing and severity

\begin{tabular}{lcccccc}
\hline & \multicolumn{2}{c}{ First Trimester } & \multicolumn{2}{c}{ Second Trimester } & \multicolumn{2}{c}{ Third Trimester } \\
SARS-CoV-2 Severity & $\begin{array}{c}\text { Exact Only } \\
(\mathbf{n = 1 3 )}\end{array}$ & $\begin{array}{c}\text { Exact/ } \\
\text { Imputed } \\
(\mathbf{n = 2 1 )}\end{array}$ & $\begin{array}{c}\text { Exact } \\
\text { Only } \\
(\mathbf{n = 3 4 )}\end{array}$ & $\begin{array}{c}\text { Exact/ } \\
\text { Imputed } \\
(\mathbf{n}=\mathbf{5 1})\end{array}$ & $\begin{array}{c}\text { Exact Only } \\
(\mathbf{n = 3 2})\end{array}$ & $\begin{array}{c}\text { Exact/ } \\
\text { Imputed } \\
(\mathbf{n}=\mathbf{3 5})\end{array}$ \\
\hline Asymptomatic & $1(7.7)$ & $9(42.9)$ & $2(5.9)$ & $19(37.3)$ & $7(21.9)$ & $10(28.6)$ \\
Mild & $12(92.3)$ & $12(57.1)$ & $32(94.1)$ & $32(62.7)$ & $21(65.6)$ & $21(60.0)$ \\
Severe & $0(0)$ & $0(0)$ & $0(0)$ & $0(0)$ & $4(12.5)$ & $4(11.4)$ \\
\hline
\end{tabular}


medRxiv preprint doi: https://doi.org/10.1101/2021.07.12.21260365; this version posted July 15, 2021. The copyright holder for this preprint (which was not certified by peer review) is the author/funder, who has granted medRxiv a license to display the preprint in perpetuity.

All rights reserved. No reuse allowed without permission.

\begin{tabular}{|c|c|c|c|c|c|c|c|c|}
\hline \multirow[b]{2}{*}{ ASQ-3 Subdomain } & \multirow[b]{2}{*}{$\begin{array}{l}\text { Overall Sample } \\
\qquad(N=107)\end{array}$} & \multirow[b]{2}{*}{$\begin{array}{c}\text { Asymptomatic } \\
(\mathrm{N}=38)\end{array}$} & \multirow[b]{2}{*}{$\begin{array}{c}\text { Mild } \\
(\mathrm{N}=65)\end{array}$} & \multirow[b]{2}{*}{$\begin{array}{l}\text { Severe } \\
(\mathrm{N}=4)\end{array}$} & \multicolumn{2}{|c|}{ Minimally Adjusted ${ }^{t}$} & \multicolumn{2}{|c|}{ Fully Adjusted ${ }^{t}$} \\
\hline & & & & & $F(D F)$ & $p$ & $F(D F)$ & $p$ \\
\hline Communication & & & & & & & & \\
\hline Mean (SD) & $47.7(9.77)$ & $49.3(9.94)$ & $46.8(9.87)$ & $46.3(4.79)$ & $0.82(2,99)$ & 0.45 & $0.80(2,82)$ & 0.45 \\
\hline Median (Min, Max) & $50.0(10.0,60.0)$ & $50.0(10.0,60.0)$ & $50.0(10.0,60.0)$ & $47.5(40.0,50.0)$ & & & & \\
\hline \multicolumn{9}{|l|}{ Gross Motor } \\
\hline Mean (SD) & $40.7(11.8)$ & $41.1(11.3)$ & $40.3(12.1)$ & $42.5(15.0)$ & $0.89(2,99)$ & 0.90 & $0.11(2,82)$ & 0.90 \\
\hline Median (Min, Max) & $40.0(10.0,60.0)$ & $40.0(20.0,60.0)$ & $40.0(10.0,60.0)$ & $40.0(30.0,60.0)$ & & & & \\
\hline \multicolumn{9}{|l|}{ Fine Motor } \\
\hline Mean (SD) & $45.1(14.0)$ & $44.7(14.6)$ & $45.0(13.8)$ & $51.3(14.4)$ & $0.44(2,99)$ & 0.64 & $0.46(2,82)$ & 0.63 \\
\hline Median (Min, Max) & $50.0(5.00,60.0)$ & $47.5(10.0,60.0)$ & $45.0(5.00,60.0)$ & $57.5(30.0,60.0)$ & & & & \\
\hline \multicolumn{9}{|l|}{ Problem Solving } \\
\hline Mean (SD) & $47.3(14.5)$ & $47.1(15.5)$ & $47.3(13.9)$ & $50.0(16.8)$ & $0.07(2,99)$ & 0.92 & $0.08(2,82)$ & 0.93 \\
\hline Median (Min, Max) & $50.0(0,60.0)$ & $50.0(0,60.0)$ & $50.0(0,60.0)$ & $57.5(25.0,60.0)$ & & & & \\
\hline \multicolumn{9}{|l|}{ Personal-Social } \\
\hline Mean (SD) & $46.7(11.6)$ & $44.1(12.9)$ & $48.3(10.5)$ & $46.3(15.5)$ & $1.69(2,99)$ & 0.19 & $1.61(2,82)$ & 0.21 \\
\hline Median (Min, Max) & $50.0(10.0,60.0)$ & $45.0(10.0,60.0)$ & $50.0(20.0,60.0)$ & $50.0(25.0,60.0)$ & & & & \\
\hline
\end{tabular}

tMinimally adjusted models included GA at birth, infant sex, and infant age at assessment. Fully adjusted models additionally controlled for maternal race, ethnicity, age at delivery, educational attainment, parity, mode of delivery, and gestational timing of SARS-CoV-2 infection. 
medRxiv preprint doi: https://doi.org/10.1101/2021.07.12.21260365; this version posted July 15, 2021. The copyright holder for this preprint (which was not certified by peer review) is the author/funder, who has granted medRxiv a license to display the preprint in perpetuity.

All rights reserved. No reuse allowed without permission.

\begin{tabular}{|c|c|c|c|c|c|c|c|c|}
\hline \multirow[b]{2}{*}{ ASQ-3 Subdomain } & \multirow[b]{2}{*}{$\begin{array}{l}\text { Overall Sample } \\
\qquad(\mathrm{N}=107)\end{array}$} & \multirow[b]{2}{*}{$\begin{array}{l}\text { First trimester } \\
(\mathrm{N}=21)\end{array}$} & \multirow[b]{2}{*}{$\begin{array}{c}\text { Second trimester } \\
(N=51)\end{array}$} & \multirow[b]{2}{*}{$\begin{array}{l}\text { Third trimester } \\
\qquad(\mathrm{N}=35)\end{array}$} & \multicolumn{2}{|c|}{ Minimally Adjusted $^{t}$} & \multicolumn{2}{|c|}{ Fully Adjusted $^{\dagger}$} \\
\hline & & & & & $F$ (DF) & $p$ & $F(D F)$ & $p$ \\
\hline Mean (SD) & $47.7(9.77)$ & $45.5(11.2)$ & $48.8(9.83)$ & $47.4(8.78)$ & $0.94(2,99)$ & 0.39 & $0.92(2,82)$ & 0.40 \\
\hline Median (Min, Max) & $50.0(10.0,60.0)$ & $45.0(10.0,60.0)$ & $50.0(10.0,60.0)$ & $50.0(20.0,60.0)$ & & & & \\
\hline \multicolumn{9}{|l|}{ Gross Motor } \\
\hline Median (Min, Max) & $40.0(10.0,60.0)$ & $35.0(10.0,55.0)$ & $40.0(10.0,60.0)$ & $40.0(15.0,60.0)$ & & & & \\
\hline \multicolumn{9}{|l|}{ Fine Motor } \\
\hline Mean (SD) & $45.1(14.0)$ & $41.2(17.2)$ & $46.1(13.9)$ & $46.1(11.9)$ & $1.04(2,99)$ & 0.35 & $1.10(2,82)$ & 0.34 \\
\hline Median (Min, Max) & $50.0(5.00,60.0)$ & $40.0(5.00,60.0)$ & $50.0(5.00,60.0)$ & $50.0(15.0,60.0)$ & & & & \\
\hline \multicolumn{9}{|l|}{ Problem Solving } \\
\hline \multicolumn{9}{|l|}{ Personal-Social } \\
\hline Mean (SD) & $46.7(11.6)$ & $44.0(15.3)$ & $47.6(10.4)$ & $47.0(10.9)$ & $0.66(2,99)$ & 0.52 & $0.64(2,82)$ & 0.53 \\
\hline Median (Min, Max) & $50.0(10.0,60.0)$ & $50.0(10.0,60.0)$ & $50.0(15.0,60.0)$ & $50.0(20.0,60.0)$ & & & & \\
\hline
\end{tabular}

tMinimally adjusted models included GA at birth, infant sex, and infant age at assessment. Fully adjusted models additionally controlled for maternal race, ethnicity, age at delivery, educational attainment, parity, mode of delivery, and gestational timing of SARS-CoV-2 infection. 
medRxiv preprint doi: https://doi.org/10.1101/2021.07.12.21260365; this version posted July 15, 2021. The copyright holder for this preprint (which was not certified by peer review) is the author/funder, who has granted medRxiv a license to display the preprint in perpetuity. All rights reserved. No reuse allowed without permission.

Table S4. Estimated marginal means of significant effects

\section{Minimally Adjusted}

ASQ-3 Subdomain

Estimated Marginal Mean \pm SE $(95 \% \mathrm{Cl})$

Gross Motor

Fine Motor

Personal-Social

\begin{tabular}{|c|c|c|c|}
\hline $\begin{array}{c}\text { Historical } \\
\text { Cohort } \\
(\mathrm{N}=62)\end{array}$ & $\begin{array}{c}\text { Pandemic } \\
\text { Cohort } \\
(\mathrm{n}=238)\end{array}$ & $\begin{array}{c}\text { Historical } \\
\text { Cohort } \\
(\mathrm{N}=62)\end{array}$ & $\begin{array}{c}\text { Pandemic } \\
\text { Cohort } \\
(\mathrm{n}=238)\end{array}$ \\
\hline
\end{tabular}

$\begin{array}{llll}45.1 \pm 1.53 & 41.3 \pm 0.74 & 45.5 \pm 2.32 & 41.9 \pm 1.82 \\ (42.1,48.1) & (39.8,42.7) & (40.9,50.1) & (38.4,45.5)\end{array}$

$\begin{array}{lccc}49.9 \pm 1.68 & 45.5 \pm 0.81 & 50.02 .51 & 45.5 \pm 1.97 \\ (46.6,53.2) & (43.9,47.1) & (45.0,54.9) & (41.6,49.4)\end{array}$

$49.6 \pm 1.47 \quad 46.8 \pm 0.716 \quad 47.8 \pm 2.22 \quad 45.0 \pm 1.75$

$(46.7,52.5) \quad(45.4,48.3) \quad(43.4,52.2) \quad(41.6,48.4)$


medRxiv preprint doi: https://doi.org/10.1101/2021.07.12.21260365; this version posted July 15, 2021. The copyright holder for this preprint (which was not certified by peer review) is the author/funder, who has granted medRxiv a license to display the preprint in perpetuity. All rights reserved. No reuse allowed without permission.

Table S5. Infant postnatal SARS-CoV-2 history

\begin{tabular}{lccc}
\hline Variable & $\begin{array}{c}\text { Overall } \\
\text { Pandemic } \\
\text { Sample } \\
\text { No. }(\%)\end{array}$ & $\begin{array}{c}\text { SARS-CoV-2 } \\
\text { Unexposed } \\
(\mathbf{N}=130)\end{array}$ & $\begin{array}{c}\text { SARS-CoV-2 } \\
\text { Exposed } \\
\mathbf{( N = 1 0 7 )}\end{array}$ \\
\hline $\begin{array}{l}\text { Result of Infant SARS-CoV-2 Test } \\
\text { Positive }\end{array}$ & $4(1.7)$ & $3(2.3)$ & $1(0.9)$ \\
$\quad$ Negative & $71(30.0)$ & $16(12.3)$ & $55(51.4)$ \\
$\quad$ Other & $3(1.3)$ & $2(1.5)$ & $1(0.9)$ \\
$\quad$ Not tested & $159(67.1)$ & $109(83.8)$ & $50(46.7)$ \\
Infant Diagnosed with SARS-CoV-2 & & & \\
$\quad$ Yes & $5(2.1)$ & $4(3.1)$ & $1(0.9)$ \\
$\quad$ No & $231(97.5)$ & $125(96.2)$ & $106(99.1)$ \\
Prefer not to answer & $1(0.4)$ & $1(0.8)$ & $0(0)$ \\
\hline
\end{tabular}


medRxiv preprint doi: https://doi.org/10.1101/2021.07.12.21260365; this version posted July 15, 2021. The copyright holder for this preprint (which was not certified by peer review) is the author/funder, who has granted medRxiv a license to display the preprint in perpetuity. All rights reserved. No reuse allowed without permission.

Table S6. Comparison of ASQ-3 subdomain scores between historical and pandemic cohorts after excluding 5 infants from the pandemic cohort who tested positive for SARS-CoV-2 or were diagnosed with COVID-19

\begin{tabular}{lccccc}
\hline & Overall & Historical & & \multicolumn{2}{c}{ Fully Adjusted } \\
\cline { 5 - 6 } $\begin{array}{l}\text { ASQ-3 Subdomain } \\
\text { Mean (SD) }\end{array}$ & $\begin{array}{c}\text { Sample } \\
\mathbf{( N = 2 9 5 )}\end{array}$ & $\begin{array}{c}\text { Cohort } \\
\mathbf{( N = 6 2 )}\end{array}$ & $\begin{array}{c}\text { Cohort } \\
(\mathbf{N = 2 3 3 )}\end{array}$ & $\boldsymbol{F ( D F )}$ & $\boldsymbol{p}$ \\
\hline Gross Motor & $42.2(11.6)$ & $46.8(10.8)$ & $41.0(11.6)$ & 12.98 & $<\mathbf{0 . 0 0 1}$ \\
Fine Motor & $46.4(12.7)$ & $51.9(12.1)$ & $45.0(12.5)$ & 15.49 & $<\mathbf{0 . 0 0 1}$ \\
Personal-Social & $47.2(11.2)$ & $50.6(8.78)$ & $46.3(11.6)$ & 7.63 & $\mathbf{0 . 0 0 6}$ \\
\hline
\end{tabular}


medRxiv preprint doi: https://doi.org/10.1101/2021.07.12.21260365; this version posted July 15, 2021. The copyright holder for this preprint (which was not certified by peer review) is the author/funder, who has granted medRxiv a license to display the preprint in perpetuity. All rights reserved. No reuse allowed without permission.

Table S7. Comparison of ASQ-3 subdomain scores between historical and pandemic cohorts after excluding 15 infants from the historical cohort assessed during the pandemic

\begin{tabular}{lcccccc}
\hline & & & & \multicolumn{2}{c}{ Fully Adjusted } \\
\cline { 5 - 7 } ASQ-3 Subdomain & $\begin{array}{c}\text { Overall } \\
\text { Mean (SD) }\end{array}$ & $\begin{array}{c}\text { Sample } \\
(\mathbf{N}=\mathbf{3 0 0})\end{array}$ & $\begin{array}{c}\text { Cohort } \\
(\mathbf{N}=\mathbf{4 7})\end{array}$ & $\begin{array}{c}\text { Pandemic } \\
\text { Cohort } \\
(\mathbf{N}=\mathbf{2 3 8})\end{array}$ & $\boldsymbol{F ( D F )}$ & $\boldsymbol{p}$ \\
\hline Gross Motor & $41.9(11.6)$ & $45.7(11.4)$ & $41.1(11.6)$ & 6.76 & $\mathbf{0 . 0 0 9}$ \\
Fine Motor & $46.2(12.6)$ & $52.1(11.9)$ & $45.1(12.5)$ & 13.48 & $<\mathbf{0 . 0 0 1}$ \\
Personal-Social & $46.8(11.2)$ & $48.9(9.03)$ & $46.3(11.6)$ & 2.23 & 0.13 \\
\hline
\end{tabular}


medRxiv preprint doi: https://doi.org/10.1101/2021.07.12.21260365; this version posted July 15, 2021. The copyright holder for this preprint (which was not certified by peer review) is the author/funder, who has granted medRxiv a license to display the preprint in perpetuity. All rights reserved. No reuse allowed without permission.

\begin{tabular}{|c|c|c|c|c|}
\hline Domain and Contrast & $\begin{array}{c}\text { Difference } \\
\text { Estimate } \pm \\
\text { Standard Error } \\
\end{array}$ & $\begin{array}{c}\text { Tukey } \\
\text { t-statistic }\end{array}$ & $\begin{array}{c}\text { Tukey } \\
\text { p-value }\end{array}$ & $\begin{array}{l}95 \% \mathrm{Cl} \text { of } \\
\text { difference }\end{array}$ \\
\hline \multicolumn{5}{|l|}{ Gross Motor } \\
\hline Trimester 1 - Historical Controls & $-4.95 \pm 2.67$ & -1.86 & 0.06 & $11.82,1.91$ \\
\hline Trimester 2 - Historical Controls & $-3.00 \pm 2.45$ & -1.23 & 0.22 & $-9.29,3.28$ \\
\hline Trimester 3 - Historical Controls & $-3.26 \pm 2.64$ & -1.23 & -0.23 & $-10.05,3.534$ \\
\hline Trimester 2 - Trimester 1 & $1.96 \pm 1.86$ & 1.05 & 0.30 & $-2.83,6.74$ \\
\hline Trimester 3 - Trimester 1 & $1.70 \pm 2.23$ & 0.76 & 0.45 & $-4.04,7.44$ \\
\hline Trimester 3 - Trimester 2 & $-0.25 \pm 1.91$ & -0.13 & 0.90 & $-5.17,4.67$ \\
\hline \multicolumn{5}{|l|}{ Fine Motor } \\
\hline Trimester 1 - Historical Controls & $-5.57 \pm 2.88$ & -1.93 & 0.05 & $-12.99,1.85$ \\
\hline Trimester 2 - Historical Controls & $-3.45 \pm 2.64$ & -1.31 & 0.19 & $-10.24,3.34$ \\
\hline Trimester 3 - Historical Controls & $-5.19 \pm 2.85$ & -1.82 & 0.07 & $-12.53,2.15$ \\
\hline Trimester 2 - Trimester 1 & $2.12 \pm 2.01$ & 1.06 & 0.29 & $-3.05,7.28$ \\
\hline Trimester 3 - Trimester 1 & $0.38 \pm 2.41$ & 0.16 & 0.88 & $-5.83,6.58$ \\
\hline Trimester 3 - Trimester 2 & $-1.74 \pm 2.06$ & -0.84 & 0.40 & $-7.05,3.57$ \\
\hline \multicolumn{5}{|l|}{ Personal-Social } \\
\hline Trimester 1 - Historical Controls & $-6.16 \pm 2.35$ & -2.62 & 0.009 & $-12.22,-0.10$ \\
\hline Trimester 2 - Historical Controls & $-4.20 \pm 2.21$ & -1.90 & 0.06 & $-9.90,1.50$ \\
\hline Trimester 3 - Historical Controls & $-3.46 \pm 2.53$ & -1.37 & 0.17 & $-9.96,3.04$ \\
\hline Trimester 2 - Trimester 1 & $1.96 \pm 1.78$ & 1.10 & 0.27 & $-2.61,6.54$ \\
\hline Trimester 3 - Trimester 1 & $2.70 \pm 2.04$ & 1.33 & 0.19 & $-2.56,7.96$ \\
\hline Trimester 3 - Trimester 2 & $0.74 \pm 1.79$ & 0.41 & 0.68 & $-3.86,5.34$ \\
\hline
\end{tabular}


medRxiv preprint doi: https://doi.org/10.1101/2021.07.12.21260365; this version posted July 15, 2021. The copyright holder for this preprint (which was not certified by peer review) is the author/funder, who has granted medRxiv a license to display the preprint in perpetuity. All rights reserved. No reuse allowed without permission.

Table S9. Raw ASQ-3 Subdomain scores by trimester of pregnancy relative to the pandemic

Trimester of pregnancy relative to peak SARS-CoV-2 cases in New York City (4/6/2020)

ASQ-3 Subdomain

Historic
Controls
$(\mathrm{N}=62)$

$\begin{array}{cc}\text { Trimester } 1 & \text { Trimester } 2 \\ (\mathrm{~N}=64) & (\mathrm{N}=112)\end{array}$

Trimester 3

$(\mathrm{N}=62)$

\section{Communication}

Mean (SD)

46.8 (9.54)

47.0 (9.99)

$48.4(10.0)$

47.9 (8.99)

Median [Min, Max]

$45.0[25.0,60.0]$

$50.0[10.0,60.0]$

$50.0[10.0,60.0]$

$50.0[20.0,60.0]$

\section{Gross Motor}

Mean (SD)

$46.8(10.8)$

39.1 (11.2)

41.3 (11.2)

42.8 (12.4)

Median [Min, Max]

$50.0[25.0,60.0]$

$40.0[10.0,60.0]$

$40.0[10.0,60.0]$

$42.5[10.0,60.0]$

Fine Motor

Mean (SD)

$51.9(12.1)$

43.0 (12.9)

45.8 (12.3)

$46.0(12.1)$

Median [Min, Max]

$60.0[0,60.0]$

$40.0[10.0,60.0]$

$45.0[5.00,60.0]$

$45.0[15.0,60.0]$

Problem Solving

Mean (SD)

$$
48.6 \text { (11.6) }
$$

45.2 (14.7)

47.8 (13.4)

49.7 (11.3)

Median [Min, Max]

$50.0[0,60.0]$

$50.0[0,60.0]$

$50.0[0,60.0]$

$55.0[15.0,60.0]$

Personal-Social

Mean (SD)

50.6 (8.78)

$43.9(12.5)$

46.9 (11.6)

$47.8(10.2)$

Median [Min, Max]

$50.0[20.0,60.0]$

$45.0[10.0,60.0]$

$50.0[5.00,60.0]$

$50.0[20.0,60.0]$ 
medRxiv preprint doi: https://doi.org/10.1101/2021.07.12.21260365; this version posted July 15, 2021. The copyright holder for this preprint (which was not certified by peer review) is the author/funder, who has granted medRxiv a license to display the preprint in perpetuity.

All rights reserved. No reuse allowed without permission.

Table S10. Estimated marginal means of personal-social scores by trimester of pregnancy relative to peak SARSCoV-2 cases in NYC (based on fully adjusted model)

ASQ-3 Subdomain

Estimated Marginal Mean \pm SE $(95 \% \mathrm{Cl})$

\begin{tabular}{cccc}
$\begin{array}{c}\text { Historical Cohort } \\
(\mathbf{N}=\mathbf{6 2})\end{array}$ & $\begin{array}{c}\text { Trimester } \mathbf{1} \\
\mathbf{( N = 6 4 )}\end{array}$ & $\begin{array}{c}\text { Trimester } \mathbf{2} \\
\mathbf{( N = 1 1 2 )}\end{array}$ & $\begin{array}{c}\text { Trimester } \mathbf{3} \\
\mathbf{( N = 6 2 )}\end{array}$ \\
\hline $49.2 \pm 2.18$ & $43.0 \pm 2.05$ & $45.0 \pm 2.00$ & $45.8 \pm 2.13$ \\
$(44.9,53.5)$ & $(39.0,47.1)$ & $(41.1,49.0)$ & $(41.6,49.9)$ \\
\hline
\end{tabular}

Personal-Social $49.2 \pm 2.18$
$(44.9,53.5)$ $(39.0,47.1)$

$(41.1,49.0)$

$(41.6,49.9)$ 